\title{
New Insights into the Life Cycle of the Wheat Powdery Mildew: Direct Observation of Ascosporic Infection in Blumeria graminis f. sp. tritici
}

\author{
Tünde Jankovics, Judit Komáromi, Attila Fábián, Katalin Jäger, Gyula Vida, and Levente Kiss
}

First and sixth authors: Plant Protection Institute, Centre for Agricultural Research, Hungarian Academy of Sciences (MTA), P.O. Box 102, H-1525 Budapest, Hungary; second, third, fourth, and fifth authors: Agricultural Institute, Centre for Agricultural Research, MTA, Brunszvik 2, H-2462 Martonvásár, Hungary; and sixth author: University of Pannonia, Georgikon Faculty, Institute of Plant Protection, Deák Ferenc u. 57, H-8360 Keszthely, Hungary.

Accepted for publication 16 February 2015.

\begin{abstract}
Jankovics, T., Komáromi, J., Fábián, A., Jäger, K., Vida, G., and Kiss, L. 2015. New insights into the life cycle of the wheat powdery mildew: Direct observation of ascosporic infection in Blumeria graminis f. sp. tritici. Phytopathology 105:797-804.

Although Blumeria graminis is an intensively studied pathogen, an important part of its life cycle (namely, the way ascospores initiate primary infections on cereal leaves) has not yet been explored in detail. This study reports, for the first time, the direct observation of this process in B. graminis f. sp. tritici using light and confocal laserscanning microscopy. All the germinated ascospores produced a single germ tube type both in vitro and on host plant surfaces; therefore, the ascosporic and conidial germination patterns are markedly different in

this fungus, in contrast to other powdery mildews. Germinated ascospores penetrated the epidermal cells of wheat leaves and produced haustoria as known in the case of conidial infections. This work confirmed earlier studies reporting that $B$. graminis chasmothecia collected from the field do not contain mature ascospores, only asci filled with protoplasm; ascospore development is induced by moist conditions and is a fast process compared with other powdery mildews. Although ascosporic infections are frequent in $B$. graminis f. sp. tritic $i$ in the field, as shown by this study and other works as well, a recent analysis of the genomes of four isolates revealed the signs of clonal or near-clonal reproduction. Therefore, chasmothecia and ascospores are probably more important as oversummering structures than genetic recombination factors in the life cycle of this pathogen.
\end{abstract}

Cereal powdery mildew is an economically important plant disease worldwide, with a persistent impact on wheat, barley, triticale, rye, and oat production. The disease is caused by different formae speciales of Blumeria graminis (39). These are the best-known powdery mildew fungi from genetic, phylogenetic, and genomic points of view and also in terms of host-pathogen interactions $(18,20,37,39,41,44)$. In the light of all these results, it may be surprising that a part of the $B$. graminis life cycle (namely, the way ascospores initiate primary infections on cereal leaves) has not been deeply explored yet. This was pointed out, for example, by Giese et al. (14) and Both and Spanu (2), who highlighted the fact that most works on $B$. graminis have been focused only on the asexual part of its life cycle. Although there were several studies which routinely applied methods to generate $B$. graminis ascospores under laboratory conditions (mostly after crossing asexual field isolates) and then infect wheat or barley leaves or leaf segments with the artificially generated ascospores in the laboratory $(3,6,19,27,32,36,43)$, none of these or any other studies have provided any details of the ascosporic infection process itself.

The germination of $B$. graminis ascospores released from the sexual fruiting bodies, called chasmothecia (formerly cleistothecia) (5), was reported as early as 1874 by Wolff (42), and later on by Salmon (35), Turner (40), Moseman and Powers (26), Koltin and Kenneth (23), and others as well. These studies have also shown that the germinated ascospores readily infected the leaves of their monocot hosts; however, the germination or the infection process

Corresponding author: L. Kiss; E-mail address: kiss.levente@agrar.mta.hu

*The $e$-Xtra logo stands for "electronic extra" and indicates that four supplementary figures and one supplementary video are published online.

http://dx.doi.org/10.1094/PHYTO-10-14-0268-R

(C) 2015 The American Phytopathological Society was not documented in any of these pioneering works. On the other hand, the early phytopathological studies have clearly shown that the dry B. graminis chasmothecia collected around harvest do not contain mature ascospores, only asci filled with protoplasm; mature ascospores were never found in asci at that developmental stage. Ascospore differentiation only starts in the presence of moisture or free water and ascospores appear in asci approximately 3 to 5 days after being immersed in water or placed in a moist environment $(23,26,40,42)$. These early studies have all recognized that chasmothecia play an important role in the oversummering and sometimes the overwintering of $B$. graminis, and the ascospores released from chasmothecia in late summer and autumn infect the young autumnsown cereals as well as volunteer plants, giving rise to asexually reproducing colonies which then overwinter as dormant mycelium on the aerial host plant surfaces $(1,9,16,23,24,40)$.

However, a direct observation of the ascosporic infection process in B. graminis has not been described in detail thus far. Therefore, in this study, we proposed to reveal, for the first time, the details of this decisive step of the $B$. graminis life cycle, focusing on structural aspects from mycological and host-parasite interaction perspectives in the case of winter wheat seedlings infected with ascospores of B. graminis f. sp. tritici.

\section{MATERIALS AND METHODS}

Plant and fungal materials. Winter wheat line MVMA/ BIPE, highly susceptible to powdery mildew infections, was used as the plant material throughout this study. A small plot of this wheat line naturally infected with powdery mildew was maintained without harvest in July 2013 until the following spring in Martonvásár, Hungary. This plot served as the main source of chasmothecia for laboratory experiments and also to monitor the natural ascospore development in the field. Samples of dry powdery mildew-infected 
leaves bearing chasmothecia (Fig. 1) were collected from the experimental plot at random every 15 to 20 days from early July until late August 2013, four times in total, examined using light microscopy, and stored in paper bags at room temperature until their use in laboratory experiments. In June 2014, 1 month before harvest, a fifth sample of leaves bearing dark-brown chasmothecia was also collected from the same wheat line grown in another part of the experimental field. Chasmothecia collected at the same time were considered as representing a single cohort; therefore, five cohorts of chasmothecia were used in this work (Supplementary Fig. S1).

Field experiments. To compare the microscopic details of ascospore development and ascosporic infections observed in our laboratory experiments (see below) with those characteristic for field conditions, young and susceptible host plant tissues were continuously made available in close vicinity to the experimental plot starting from July 2013, right after the first masses of black chasmothecia became visible on the already partially or completely withered old wheat plants. This was achieved by sowing wheat seed around the experimental plot in July 2013. The emerging young plants were watered as needed and visually checked every 2 to 3 days for the emergence of young powdery mildew colonies. To monitor the natural ascospore development in the experimental field plot, 5 to 10 dry leaf samples covered with powdery mildew mycelium containing chasmothecia (Fig. 1) were collected randomly from the experimental plot at 1-week intervals and taken to the laboratory, where a number of chasmothecia from each leaf sample were crushed on microscope slides and the asci were checked under a light microscope for the presence of ascospores.

Ascospore differentiation and germination in vitro. To induce ascospore development in vitro in chasmothecia coming from the experimental plot, chasmothecia were collected from dry wheat leaves with glass needles under a stereomicroscope and placed in empty 1.5-ml Eppendorf tubes. At least 200 to 250 chasmothecia were put in each tube. Two tubes were prepared in this way for each of the four cohorts of chasmothecia collected in July to August 2013. Sterile distilled water $(1 \mathrm{ml})$ was pipetted into one of the two tubes with chasmothecia representing the same cohort; the chasmothecia in the other tube, coming from the same cohort, remained dry to serve as a control. The eight tubes were incubated in a dark climate chamber at $20^{\circ} \mathrm{C}$ for 5 days. Approximately 20 to 25 chasmothecia were retrieved from each tube every $24 \mathrm{~h}$, crushed in a drop of water on a microscope slide, with or without subsequent staining with cotton blue in lactophenol, and examined under a light microscope. The experiment was carried out four times from September 2013 to July 2014 with each of the four cohorts collected in 2013.

Inoculations of wheat leaves with ascospores released spontaneously from chasmothecia. Wheat seedlings were grown from seed in five UV-sterilized transparent plastic boxes covered with sterile transparent foil in a climate chamber at $20^{\circ} \mathrm{C}$

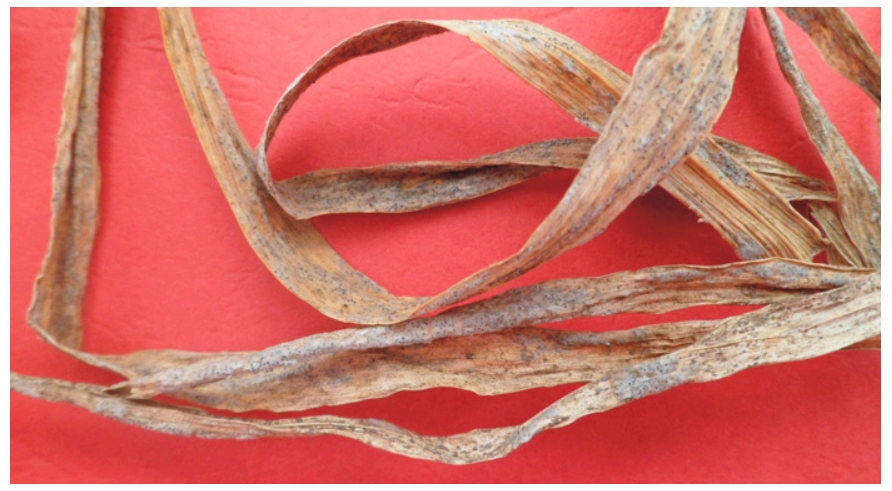

Fig. 1. Dry powdery mildew-infected wheat leaves collected from the experimental plot and used in this study as sources of chasmothecia. under $16 \mathrm{~h}$ of illumination. The climate chamber was heat sterilized before each experiment to ensure that no conidia of $B$. graminis $\mathrm{f}$. sp. tritici were present there and was situated in a building where B. graminis f. sp. tritici has never been maintained on experimental plants. Approximately 100 seedlings were grown in each box until the shoot tips emerged from the coleoptiles. At that stage, seedlings received the following treatments. (i) Dry leaf segments approximately $10 \mathrm{~cm}$ long bearing chasmothecia were submerged in sterile distilled water for $1 \mathrm{~h}$. These were then fixed horizontally on sticks so that they formed a mesh around the seedlings grown in the box (Supplementary Fig. S2). (ii) Chasmothecia embedded in secondary mycelium were scraped off the dry leaf samples after soaking them in sterile distilled water for $1 \mathrm{~h}$ and a piece of mycelium containing 10 to 20 chasmothecia was placed on the tip of each seedling. Each of the two treatments carried out to infect seedlings with ascospores released from chasmothecia was performed in two plastic boxes. One box remained untreated in the climate chamber to serve as a control and also to provide older seedlings for inoculations with ascospore suspensions (see below). Seedlings in the boxes, including the controls, were sprayed with sterile water once a day. The experiment was continued until the first visible symptoms appeared on the seedlings, and was carried out three times with a cohort of chasmothecia collected in July 2013 and twice with the cohort of chasmothecia collected in June 2014.

Light microscopy. To observe the details of the ascosporic infections, five seedlings were taken from each box per day and prepared for light microscopic studies. Leaves were cut into segments of approximately $5 \mathrm{~cm}$ in length, and the segments were fixed in the mixture of acetic acid and ethanol (1:1) for 2 days, followed by a treatment in $1 \%$ hydrochloric acid for $30 \mathrm{~min}$. Leaf segments were stained with cotton blue in lactophenol for $5 \mathrm{~min}$ and rinsed in a mixture of $0.5 \%$ hydrochloric acid and $25 \%$ glycerol. Segments were mounted on microscopic slides in $50 \%$ glycerol for light microscopy. During microscopic observations, the following features were examined: presence or absence of germ tubes developed by ascospores; number and position of germ tubes, if found; penetration of epidermal cells and haustorium formation; and colony development from early stages until the first conidiophores appeared.

Confocal laser-scanning microscopy. Leaf segments exposed to spontaneously released ascospores in plastic boxes as described above were examined with confocal laser-scanning microscopy (CLSM), as well.

In order to visualize the fungal structures and host-pathogen interactions during ascosporic infections, including callose deposition at penetration sites, leaf segments were fixed in a mixture of acetic acid and ethanol (1:1) for 1 day, then stained with aniline blue $(5 \mathrm{mg} / \mathrm{ml}$ in $0.07 \mathrm{M}$ sodium phosphate buffer, $\mathrm{pH} 9)$ for $1 \mathrm{~h}$. The segments were mounted on microscopic slides in water and examined under a light microscope in order to find germinating ascospores and young ascosporic colonies. The selected leaf segments were saturated with aniline blue by adding dye under the cover slip and were stained overnight. Fluorescence from aniline blue staining and autofluorescence from plant structural elements, including cell walls, cuticle, and epicuticular wax, were imaged by a Leica TCS SP8 confocal laser-scanning microscope (Leica, Germany). Samples were excited by LASOS diode laser at $405 \mathrm{~nm}$ and fluorescent signals were detected at wavelengths between 480 and $520 \mathrm{~nm}$. Z-series image acquisition and building of threedimensional reconstructions were carried out using LAS (Leica Application Suite) Advanced Fluorescence program.

\section{RESULTS}

Field observations. Approximately 500 chasmothecia collected from the dry leaves of the nonharvested plot were examined weekly starting from the harvest until mid-October 2013. In July, chasmothecia were mostly lenticular (i.e., lens-shaped) and depressed and were always embedded in a dense, white mat of 
bristle-like, falcate (i.e., sickle-shaped), thick-walled, and aseptate secondary hyphae (Fig. 2A). Secondary hyphae, which are structures characteristic of B. graminis (4), formed nest-like mycelial structures encompassing chasmothecia firmly in this period. Starting from August, gradual collapse of this mycelial structure was observed. Chasmothecia became concave at the upper side by the end of summer (Fig. 2B). None of the chasmothecia collected in July and August contained asci with differentiated ascospores inside. In early September 2013, following three rainy days, maturation and dehiscence of chasmothecia were observed on all the leaves collected from the nonharvested experimental plot (Fig. 2C). Starting from early October, no chasmothecia containing ascospores were found on any of the leaves examined.

In summer, no powdery mildew symptoms were observed on the young seedlings grown in close vicinity of the experimental plot. This indicated that no B. graminis inoculum was present in the experimental site after harvest. The first powdery mildew colonies were found on the young plants in early September, 5 days after the first microscopic detection of the dehiscence of chasmothecia collected regularly from the nonharvested plants (Fig. 2C). The symptoms first appeared on the seedlings grown next to the plot. At that stage, no symptoms were observed on the seedlings located more than $0.5 \mathrm{~m}$ from the plot. This suggested that the first visible colonies were derived from ascospores rather than conidia in the field. Young colonies, when visible, had already produced conidia in abundance, and their ascosporic origin could not be confirmed by microscopy. The asexual stage of the pathogen became widespread on the infected young leaves in a few days, and the disease spread throughout the young seedling population in 1 week.

Ascospore differentiation and germination in vitro. Ascospores were differentiated in most chasmothecia that were submerged in water in Eppendorf tubes for approximately 48 to $72 \mathrm{~h}$ in all the five cohorts; thus, regardless of the date of collection. No ascospores developed in any chasmothecia kept dry in the tubes.

At the beginning of each experiment, when crushed on microscope slides in a drop of water, chasmothecia were either empty or contained asci filled with protoplasm without differentiated ascospores (Fig. 3A). After $48 \mathrm{~h}$, ascospores surrounded by protoplasm appeared within asci in most chasmothecia submerged in water (Fig. 3B). After $72 \mathrm{~h}$, most of the protoplasm disappeared from asci which, at that stage, contained only well-differentiated ascospores (Fig. 3C).

Germination of ascospores, when released in water in Eppendorf tubes, was frequently observed. In water, ascospores produced mostly one (Fig. 3D and E) or sometimes two germ tubes each (Fig. 3F). Germ tubes were simple, straight, sometimes branched
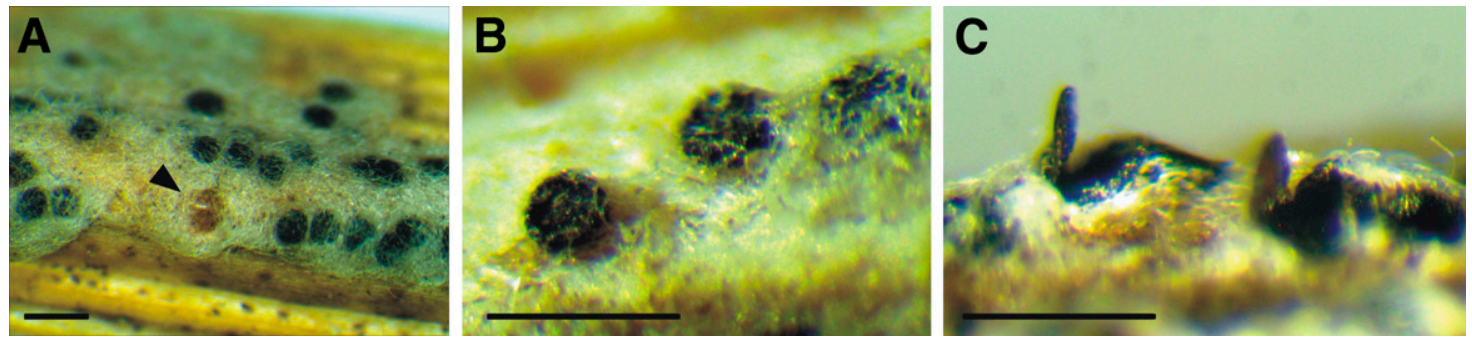

Fig. 2. Developmental stages of Blumeria graminis f. sp. tritici chasmothecia observed in July, August, and September 2013 in the experimental plot (a nonharvested plot of the winter wheat line MVMA/BIPE). A, Immature chasmothecia of lenticular (depressed) shape embedded in a dense mycelial structure consisting of secondary hyphae of B. graminis. Arrowhead indicates a nest-like hole in the mycelium where a chasmothecium was eliminated from. B, Concave immature chasmothecia. Note the partial collapse of the surrounding mycelium. $\mathbf{C}$, Two dehisced chasmothecia after ascospore release. Bar $=300 \mu \mathrm{m}$.
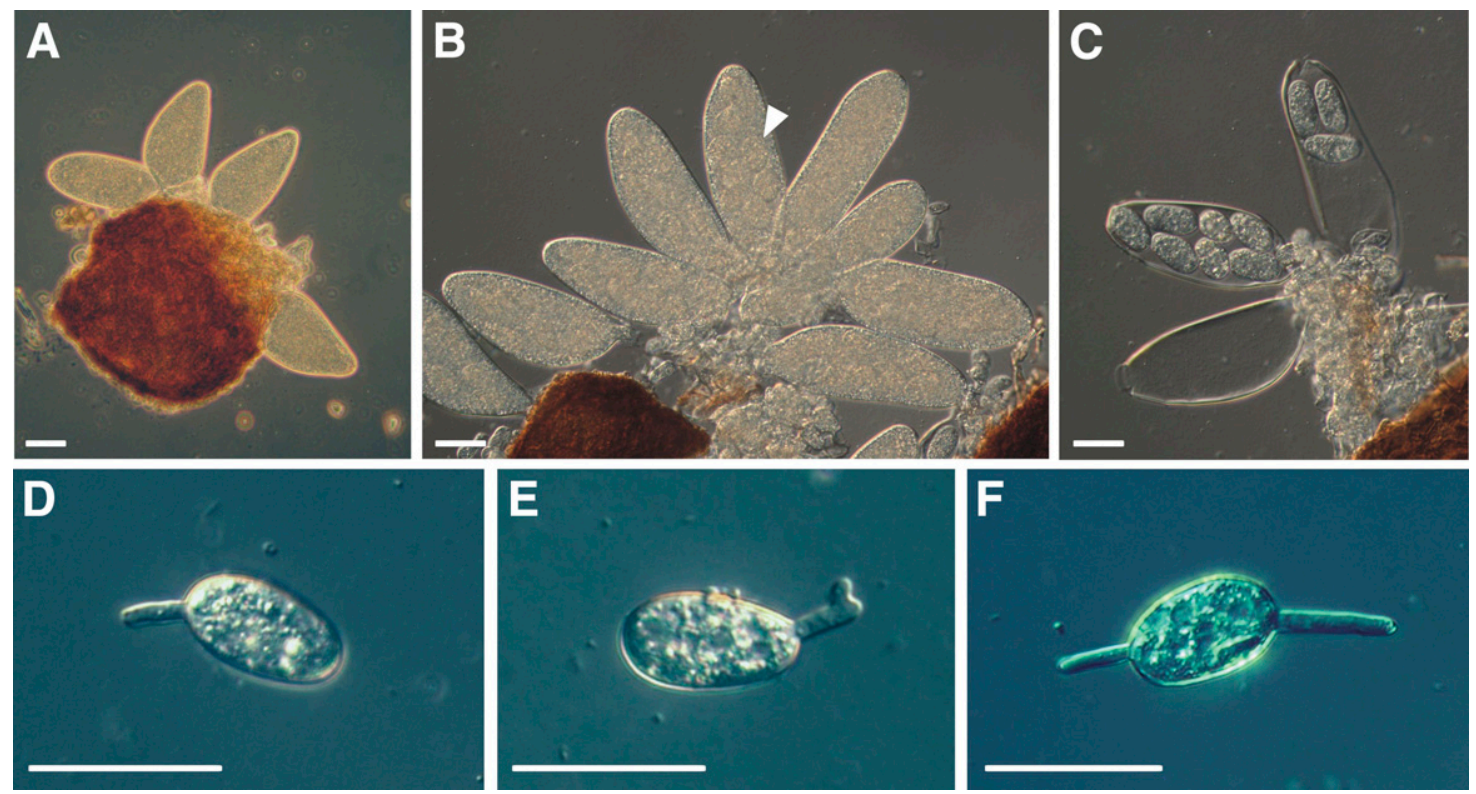

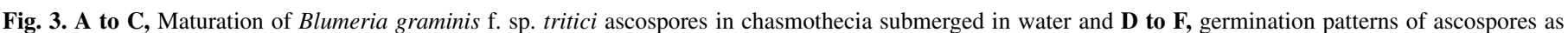

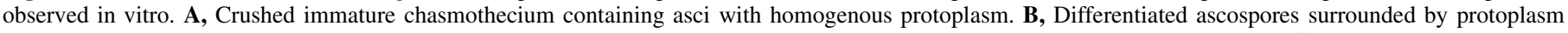

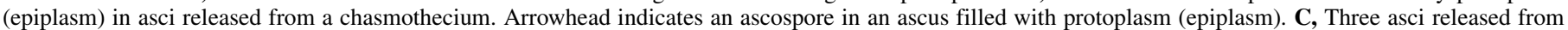

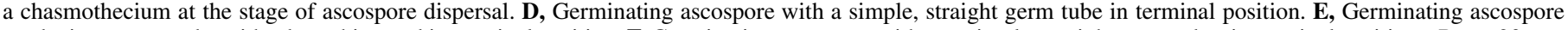

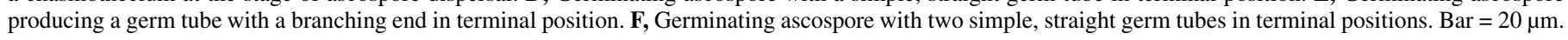


(Fig. 3E), ended with rounded apices, without producing lobed appressoria, and were always shorter than the length of ascospores. Germ tubes arose from a terminal or subterminal position. When two germ tubes were formed, they usually arose from the opposite ends of the ascospore. Elongation of ascosporic germ tubes and formation of septate hyphae were not observed in vitro.

Germination of ascospores and early colony development on living host plant tissues. Altogether, approximately 200 germinating ascospores and ascospore-originated young powdery mildew colonies were observed on the living host tissues in this study. The ascosporic colony development was the same in all the experimental boxes containing wetted leaf segments bearing chasmothecia and those in which mycelial pieces with chasmothecia were placed on the seedlings to serve as sources of ascospore inoculum.

In the case of the chasmothecial cohort collected in July 2013, the very first germinating ascospores on wheat seedlings were detected under the light microscope 3 days after the chasmothecia had been placed in the experimental boxes. The majority of the germinating ascospores were observed 5 days after inoculation, while no new germinating ascospores were found on the leaves 7 days after placing wetted chasmothecia in the boxes. This was consistent in all three experiments done with chasmothecia collected in July 2013. The first macroscopically visible symptoms appeared 10 days after the start of the experiments; thus, 5 to 7 days after the first steps of the ascosporic infections.
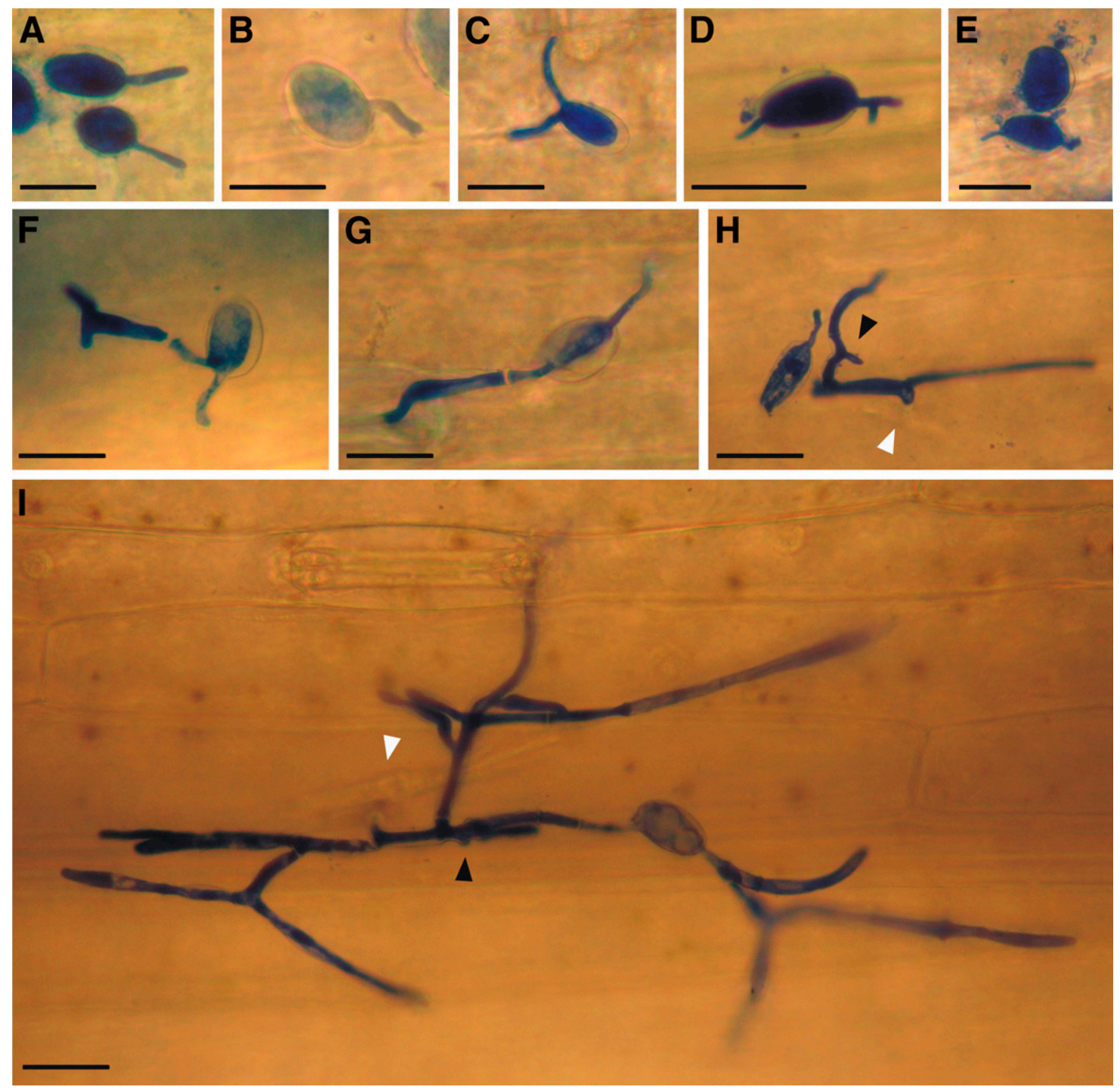

Continued on next page

Fig. 4. Consecutive steps of ascosporic infection of winter wheat line MVMA/BIPE by Blumeria graminis f. sp. tritici consisting of A to G, ascospore germination; $\mathbf{H}$, penetration of epidermal cells and haustorium formation; and $\mathbf{I}$ to $\mathbf{N}$, early colony development. Various patterns of ascospore germination and hyphal growth are presented at each stage. A, Two ascospores with one single germ tube each in terminal position. B, Ascospore with a single germ tube in subterminal position. C, Ascospore with two germ tubes from the same end of the ascospore. D, Ascospore with two terminal germ tubes from opposite ends of the ascospore; one of the germ tubes is branched. E, Two germinating ascospores, one of them with three germ tubes in terminal, subterminal, and lateral positions each. F and G, Ascospores with two germ tubes, one of them elongated, septate, and swelled toward the tip. H, Young colony initial originated from an ascospore which produced three germ tubes. Two of these remained short and one elongated and penetrated an epidermal cell. White arrowhead indicates the penetration site and a haustorium beneath, while the black arrowhead shows the colony-forming ascospore that has been shriveled. Another germinating ascospore is also visible. I, Young ascosporic powdery mildew colony with a haustorium developed inside the epidermal cell (white arrowhead) and hyphae bearing appressoria (black arrowhead). $\mathbf{J}$ and K, Young colonies developed from ascospores (arrowheads) that produced multiple germ tubes. Some germ tubes remained short. L and M, More developed ascosporic colonies at a stage preceding conidiogenesis. Arrowheads indicate the colony forming ascospores with multiple germ tubes. N, Part of an ascosporic colony with young conidiophores and conidiophore initials. The colony was developed from an ascospore (arrowhead) which produced one single germ tube. Bar $=$ $20 \mu \mathrm{m}$. 
In contrast, the whole process needed more time in the experimental boxes which contained chasmothecia collected in June 2014, 1 month before harvest. In both experiments, the first germinating ascospores were found on the young leaves only 10 days after placing the chasmothecia in the boxes. The first visible powdery mildew colonies appeared on the seedlings 4 to 5 days later.

Each germinating ascospore produced one to four germ tubes on the seedlings. Germ tubes were mostly simple, straight (Fig. 4A) or somewhat curved (Fig. 4B and C), sometimes branched (Fig. 4D), ended with rounded apices, without producing lobed appressoria, and were shorter than or the same size as the length of ascospores. Their positions were terminal (Fig. 4A), subterminal (Fig. 4B), or lateral (Fig. 4E). Formation of two to four germ tubes per ascospore was observed frequently (Fig. $4 \mathrm{C}$ to E). Multiple germ tubes were found to be produced all from the same end (Fig. 4C) or from the opposite ends of the ascospore (Fig. 4D and E). By the elongation of
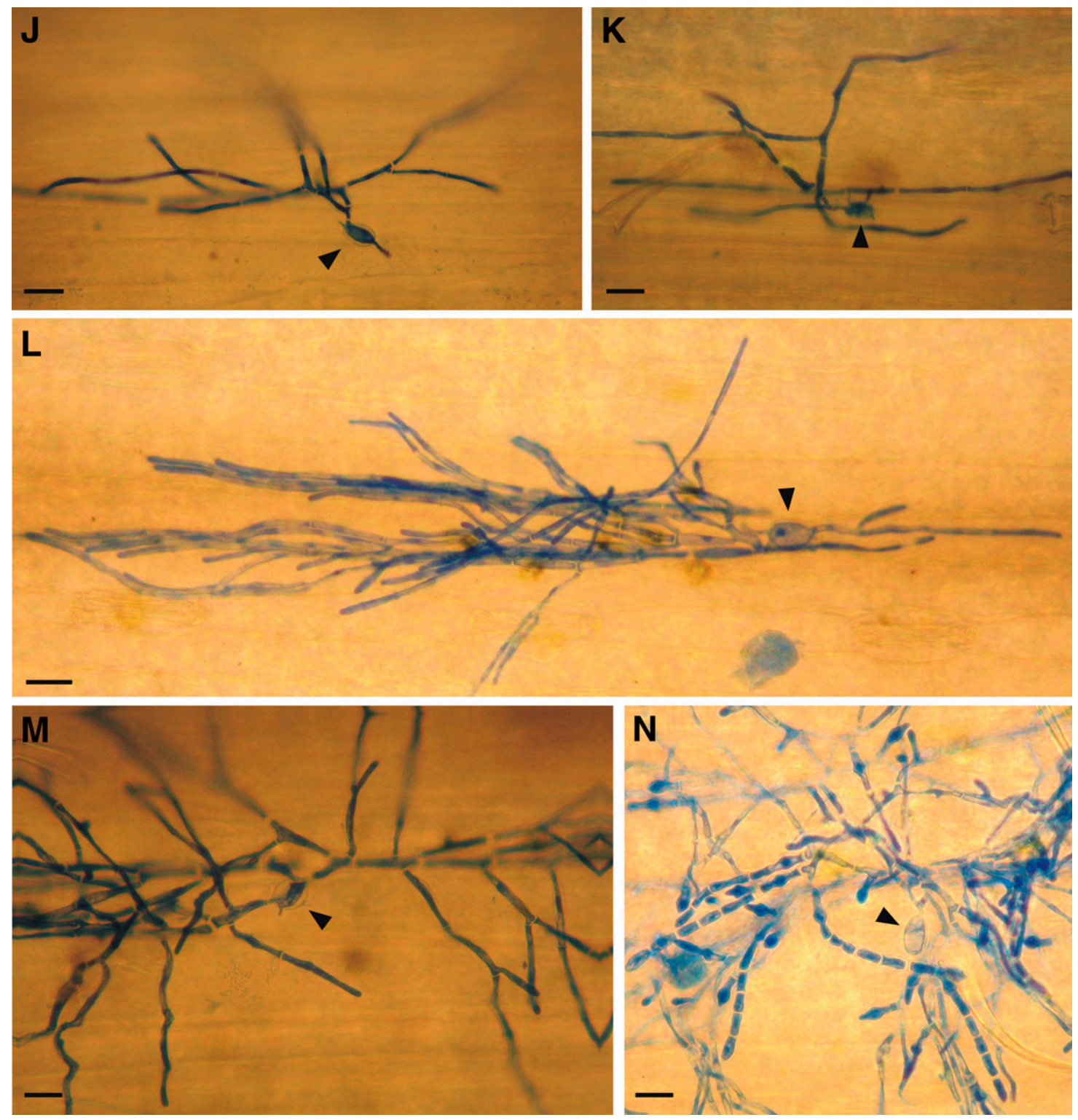

Fig. 4. Continued from previous page.
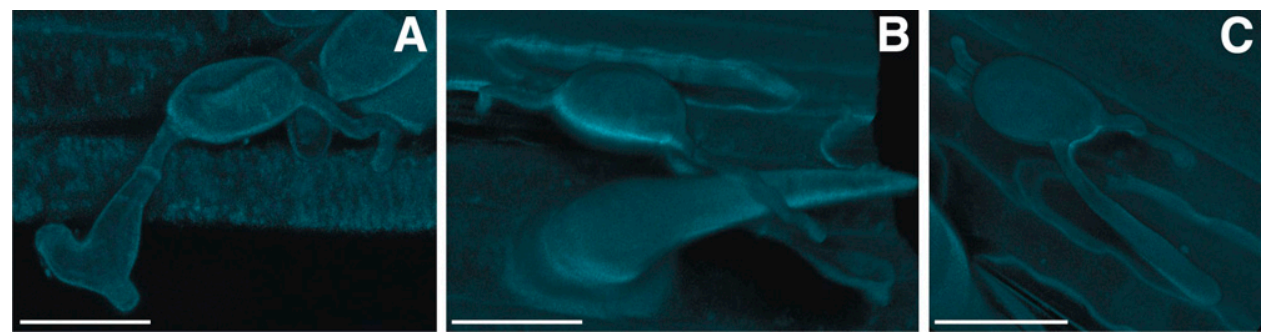

Fig. 5. Three-dimensional reconstructions of three germinated Blumeria graminis f. sp. tritici ascospores on the host leaf surface. A, Ascospore with two germ tubes, the septate one exhibiting a remarkable swelling with hyphal branching at the tip. B, Ascospore with three germ tubes. C, Ascospore with four germ tubes of different lengths. Bar $=20 \mu \mathrm{m}$. 
germ tubes, germinated ascospores produced septate hyphae that were usually swelled toward the tips (Figs. 4F and G; 5A to C; Supplementary Fig. S3). This was followed by the production of a penetration peg and formation of a haustorium inside the epidermal cell of the host (Figs. 4H and I; 6; Supplementary Video; Supplementary Figs. S3 and S4). Following haustorium development, septate hyphae continued their growth, initiating the formation of young colonies (Fig. 4I to M). In some cases, all germ tubes produced by the same ascospore developed into septate hyphae and contributed to colony formation (Fig. 4I and N) whereas, in other cases, some germ tubes remained short even after colonies have already been developed (Figs. $4 \mathrm{~J}$ to M; 6). At 3 to 5 days following the detection of the first germinating ascospores on the young leaves, the first conidiophore initials and young conidiophores with undifferentiated conidia were observed in the powdery mildew colonies (Fig. 4N).

Host-pathogen interactions in ascosporic infections. Light microscopy revealed the formation of a papilla-like thickening of the epidermal cell wall at the penetration point of the ascospore-derived hypha. This was more evident using CLSM (Fig. 6). Staining with aniline blue, a dye mainly used to visualize callose, has indicated callose accumulation at penetration sites (Fig. 6).

\section{DISCUSSION}

In sharp contrast to the conidial stage of powdery mildews, which has been intensively studied for a long time from many perspectives $(2,4,14,17)$, very little is known about the ascosporic infections in these plant pathogens. This is probably due to the fact that the direct observation of the release and germination of ascospores is very difficult in any powdery mildew species, whereas the abundant, long-term, and synchronized production of conidia is a relatively easy process to follow $(25,29)$. Also, the detection of young powdery colonies originated from ascosporic infections is problematic $(6,8,33)$ because these quickly start sporulating in an asexual way; therefore, soon after the formation of the first ascospore-derived colonies, the distinction between these colonies and those initiated by conidia is practically impossible.

To date, the morphology of germinating ascospores was studied experimentally and documented in detail in only 2 powdery mildew species out of the approximately 850 species known worldwide. In Erysiphe necator, ascospore germination patterns followed the characteristics of the germinating conidia (i.e., each ascospore produced one or more germ tubes which ended in simple or lobed appressoria) $(11,13,30)$. Germinating ascospores of Phyllactinia moricola infecting mulberry exhibited similar patterns (21). The
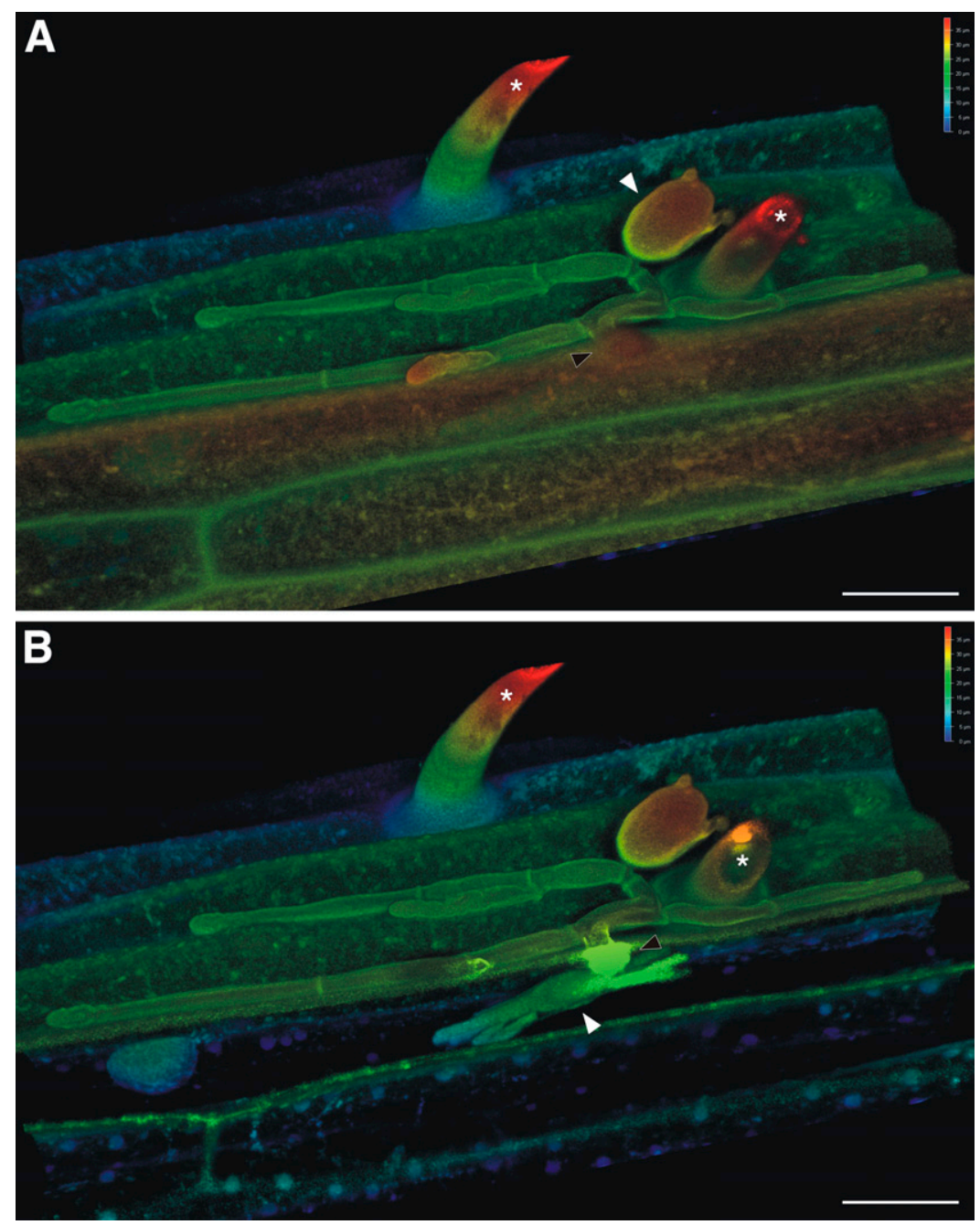

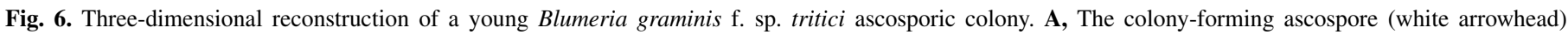

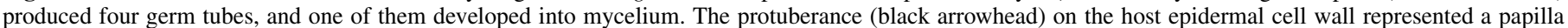

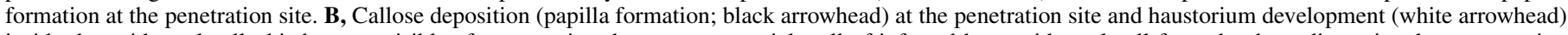

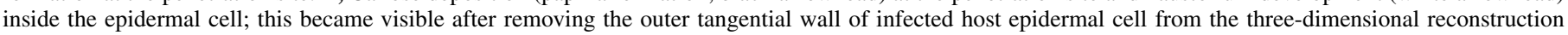

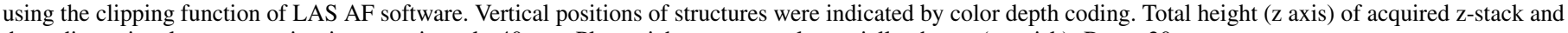
three-dimensional reconstruction is approximately $40 \mu \mathrm{m}$. Plant trichomes are only partially shown $($ asterisk). Bar $=20 \mu \mathrm{m}$. 
conidial germination patterns (i.e., the site of emergence of germ tubes from the conidial body), the morphology of the germ tube appressoria, and so on are all stable characteristics used for species identification purposes (7). Because $B$. graminis conidia germinate in a special way, producing two types of germ tubes-primary tubes, which never penetrate the host cells, and longer and thicker secondary tubes, which produce penetration hyphae-the present study offered a good opportunity to verify whether conidial and ascosporic germination patterns are alike in B. graminis from a morphological point of view, similar to what was found in $E$. necator and $P$. moricola. However, all the germinated $B$. graminis ascospores produced a single germ tube type; therefore, our study showed that the ascosporic and the conidial germination patterns are markedly different in B. graminis f. sp. tritici.

Recently, it has been recognized that the body of the already germinated conidium can serve as a site for conidiogenesis, in addition to the cells of the hyphae; this process, described as microcyclic conidiogenesis sensu lato by Kiss et al. (22), was detected in conidia of $B$. graminis and those of several other powdery mildew species, as well (31). This phenomenon was not detected during ascosporic infections examined in this work.

The differentiation and the dispersal of ascospores was studied in B. graminis, as well as in several other powdery mildews, in more detail than the direct observation of ascospore germination patterns. Our studies confirmed earlier works $(23,26,27,35,40,42)$ reporting that the development of $B$. graminis ascopores within asci filled up with undifferentiated protoplasm is a relatively fast process and it is induced by moist conditions. We found that mature ascospores were produced in approximately 3 days in chasmothecia collected from the nonharvested experimental plot from early July until late August 2013 when these were kept in water or in boxes under continuous moisture. In these latter conditions, the majority of the freshly differentiated ascospores were released from chasmothecia and already produced germ tubes on wheat leaves in approximately 5 days after the beginning of the experiment. This process was longer, up to 10 days, in chasmothecia collected in June 2014, 1 month before harvest. Earlier works reported the differentiation of B. graminis f. sp. tritici and f. sp. hordei ascospores in 3 days (23), 3 to 5 days $(35,40), 5$ to 8 days (42), 4 to 6 days (27), and 6 to 11 days (26) in water or in moist environments and under slightly variable temperature values. A longer period, up to 11 days, was reported for ascospore differentiation in chasmothecia collected early in the spring (23), similar to our findings, which should be regarded as results coming from a small-scale field observation of this process. A comprehensive study has also revealed that the age of chasmothecia influenced the timing of ascospore dispersal in the field (40). Undifferentiated asci may remain viable in dry chasmothecia for exceptionally long periods: ascospore differentiation was successfully induced in B. graminis f. sp. hordei chasmothecia kept for 13 years at $10^{\circ} \mathrm{C}(26)$. Asci containing differentiated ascospores are only rarely found in herbarium specimens of B. graminis (4); it is likely that these rare specimens, exhibiting ascospores in their asci, were kept moist for some time before conservation.

In a number of powdery mildew fungi, the maturation of ascospores is a lengthy process compared with $B$. graminis and may take several weeks or even months. Moreover, in some species, morphologically differentiated ascospores detected in asci may not always be physiologically mature, as shown in E. necator (13) and Podosphaera aphanis infecting strawberry (10). In these two species, ascospores artificially released from chasmothecia before being physiologically mature often burst in water rather than starting to germinate $(10,13)$. To our knowledge, this was never observed in $B$. graminis, where the morphologically quickly differentiated ascospores were always ready to infect their hosts. This was shown in earlier works $(23,26,27,35,42)$ and in this study, as well.

In many powdery mildew species, ascospores are morphologically mature by the end of the season (4) whereas, in Neö̈rysiphe,
Parauncinula, and other species, asci produced by the end of the season remain undifferentiated, just as in B. graminis, and ascospores appear in the asci after overwintering, right before their dispersal $(4,28,34,38)$. In $E$. necator, ascospores produced in autumn can even be released at that time without contributing to the early epidemics in the following spring (33).

It has long been a general belief that ascosporic infections initiate the life cycles of many powdery mildews $(4,8,12,13,15,30)$, including B. graminis $(1,6,19,24,42,45)$. Also, crossing B. graminis isolates with distinct fungicide resistance and virulence patterns has shown that the sexual process does lead to genetic recombination because the patterns of ascosporic progenies were different from those of the crossed isolates $(3,6,19,27,32,36,43)$. However, although it seems that ascosporic infections resulting from sexual recombinations are frequent in $B$. graminis f. sp. tritici in the field, as shown by this study and many other works as well, a recent comparison of the genomes of four isolates coming from different geographic regions revealed the signs of clonal or near-clonal reproduction (41). Therefore, chasmothecia and ascospores are probably much more important as oversummering structures of $B$. graminis f. sp. tritici than overall genetic recombination factors in the life cycle of this pathogen.

\section{ACKNOWLEDGMENTS}

We thank Z. Bognár for his assistance in field experiments, L. Láng for providing the winter wheat line used in this study, and S. Takamatsu and I. J. Holb for helpful discussions. L. Kiss's work in this study was supported by the European Union and the State of Hungary, co-financed by the European Social Fund in the framework of TÁMOP-4.2.4.A/2-11-1-2012-0001 National Excellence Program. This work was also partly supported by the János Bolyai Research Scholarship of the Hungarian Academy of Sciences (MTA) awarded to T. Jankovics and two grants of the Hungarian Scientific Research Fund (OTKA NN 100415 and PD 112468). Acquisition of the Leica SP8 confocal laser scanning microscope was funded by a Research Infrastructure Grant of the Hungarian Academy of Sciences (GENPROF IF18/2012).

\section{LITERATURE CITED}

1. Anonymous. 2008. The Encyclopaedia of Cereal Diseases. Home Grown Cereals Authority (HGCA), Kenilworth, United Kingdom.

2. Both, M., and Spanu, P. D. 2004. Blumeria graminis f. sp. hordei, an obligate pathogen of barley. Annu. Plant Rev. 11:202-218.

3. Bousset, L., and Vallavieille-Pope, C. 2003. Effect of sexual recombination on pathotype frequencies in barley powdery mildew populations of artificially inoculated field plots. Eur. J. Plant Pathol. 109:13-24.

4. Braun, U., and Cook, R. T. A. 2012. Taxonomic Manual of the Erysiphales (Powdery Mildews). CBS-KNAW Fungal Biodiversity Centre, Utrecht, The Netherlands.

5. Braun, U., Cook, R. T. A., Inman, A. J., and Shin, H. D. 2002. The taxonomy of the powdery mildew fungi. Pages 13-55 in: The Powdery Mildews: A Comprehensive Treatise. R. R. Bélanger, W. R. Bushnell, A. J. Dik, and T. L. W. Carver, eds. American Phytopathological Society, St. Paul, MN.

6. Brown, J. K. M., Jessop, A. C., Thomas, S., and Rezanoor, H. N. 1992. Genetic control of the response of Erysiphe graminis f. sp. hordei to ethirimol and triadimenol. Plant Pathol. 41:126-135.

7. Cook, R. T. A., and Braun, U. 2009. Conidial germination patterns in powdery mildews. Mycol. Res. 113:616-636.

8. Desprez-Loustau, M. L., Vitasse, Y., Delzon, S., Capdevielle, X., Marçais, B., and Kremer, A. 2010. Are plant pathogen populations adapted for encounter with their host? A case study of phenological synchrony between oak and an obligate fungal parasite along an altitudinal gradient. J. Evol. Biol. 23:87-97.

9. Frauenstein, K., Frohs, M., and Haase, E. 1980. Untersuchungen zur Reifezeit der Kleistothezien von Erysiphe graminis DC. f. sp. tritici Marchal. Arch. Phytopathol. Pflanzenschutz 16:89-93.

10. Gadoury, D. M., Asalf, B., Heidenreich, M. C., Herrero, M. L., Welser, M. J., Seem, R. C., Tronsmo, A. M., and Stensvand, A. 2010. Initiation, development, and survival of cleistothecia of Podosphaera aphanis and their role in the epidemiology of strawberry powdery mildew. Phytopathology 100:246-251.

11. Gadoury, D. M., Cadle-Davidson, L., Wilcox, W. F., Dry, I. B., Seem, R. C., and Milgroom, M. G. 2012. Grapevine powdery mildew (Erysiphe 
necator): A fascinating system for the study of the biology, ecology and epidemiology of an obligate biotroph. Mol. Plant Pathol. 13:1-16.

12. Gadoury, D. M., and Pearson, R. C. 1990. Ascocarp dehiscence and ascospore discharge in Uncinula necator. Phytopathology 80:393-401.

13. Gadoury, D. M., and Pearson, R. C. 1990. Germination of ascospores and infection of Vitis by Uncinula necator. Phytopathology 80:11981203.

14. Giese, H., Hippe-Sanwald, S., Somerville, S., and Weller, J. 1997. Erysiphe graminis. Pages 55-77 in: The Mycota V, Part B, Plant Relationships. G. C. Carroll and P. Tudzynski, eds. Springer-Verlag, Berlin.

15. Glawe, D. A. 2008. The powdery mildews: A review of the world's most familiar (yet poorly known) plant pathogens. Annu. Rev. Phytopathol. 46: 27-51.

16. Götz, M., Friedrich, S., and Boyle, C. 1996. Development of cleistothecia and early ascospore release of Erysiphe graminis DC. f. sp. tritici in winter wheat in relation to host age and climatic conditions. J. Plant Dis. Prot. 103:134-141.

17. Green, J. R., Carver, T. L. W., and Gurr, S. J. 2002. The formation and function of infection and feeding structures. Pages 66-82 in: The Powdery Mildews: A Comprehensive Treatise. R. R. Bélanger, W. R. Bushnell, A. J. Dik, and T. L. W. Carver, eds. American Phytopathological Society, St. Paul, MN.

18. Hacquard, S., Kracher, B., Maekawa, T., Vernaldi, S., Schulze-Lefert, P., and van Themaat, E. V. L. 2013. Mosaic genome structure of the barley powdery mildew pathogen and conservation of transcriptional programs in divergent hosts. Proc. Natl. Acad. Sci. USA 110:E2219-E2228.

19. Hollomon, D. W. 1981. Genetic control of ethirimol resistance in a natural population of Erysiphe graminis f. sp. hordei. Phytopathology 71: 536-540

20. Inuma, T., Khodaparast, S. A., and Takamatsu, S. 2007. Multilocus phylogenetic analysis within Blumeria graminis, a powdery mildew fungus of cereals. Mol. Phylogenet. Evol. 44:741-751.

21. Itoi, S., Nakayama, K., and Kubomura, Y. 1962. Studies on the powdery mildew disease of mulberry tree caused by Phyllactinia moricola (P. Henn.). Homma. Bull. Imp. Sericult. Exp. Stn. 17:321-445.

22. Kiss, L., Pintye, A., Zséli, G., Jankovics, T., Szentiványi, O., Hafez, Y. M., and Cook, R. T. A. 2010. Microcyclic conidiogenesis in powdery mildews and its association with intracellular parasitism by Ampelomyces. Eur. J. Plant Pathol. 126:445-451.

23. Koltin, Y., and Kenneth, R. 1970. The role of the sexual stage in the oversummering of Erysiphe graminis DC. f. sp. hordei Marchal under semiarid conditions. Ann. Appl. Biol. 65:263-268.

24. Liu, N., Gong, G., Zhang, M., Zhou, Y., Chen, Z., Yang, J., Chen, H., Wang, X., Lei, Y., and Liu, K. 2012. Over-summering of wheat powdery mildew in Sichuan Province, China. Crop Prot. 34:112-118.

25. Moriura, N., Matsuda, Y., Oichi, W., Nakashima, S., Hirai, T., Sameshima, T., Nonomura, T., Kakutani, K., Kusakari, S., Higashi, K., and Toyoda, H. 2006. Consecutive monitoring of lifelong production of conidia by individual conidiophores of Blumeria graminis f. sp. hordei on barley leaves by digital microscopic techniques with electrostatic micromanipulation. Mycol. Res. 110:18-27.

26. Moseman, J. G., and Powers, H. R., Jr. 1957. Function and longevity of cleistothecia of Erysiphe graminis f. sp. hordei. Phytopathology 47:53-56.

27. Niewoehner, A. S., and Leath, S. 1998. Virulence of Blumeria graminis f. sp. tritici on winter wheat in the eastern United States. Plant Dis. 82: 64-68.

28. Nomura, Y. 1983. Notes on the ascospores of Uncinula septata. Trans. Mycol. Soc. Jpn. 24:231-233.

29. Nonomura, T., Matsuda, Y., Xu, L., Kakutani, K., Takikawa, Y., and Toyoda, H. 2009. Collection of highly germinative pseudochain conidia of Oidium neolycopersici from conidiophores by electrostatic attraction. Mycol. Res. 113:364-372.
30. Pearson, R. C., and Gadoury, D. M. 1987. Cleistothecia, the source of primary inoculum for grape powdery mildew in New York. Phytopathology 77:1509-1514.

31. Pintye, A., Legler, S. E., and Kiss, L. 2011. New records of microcyclic conidiogenesis in some powdery mildew fungi. Mycoscience 52:213-216.

32. Robinson, H. L., Ridout, C. J., Sierotzki, H., Gisi, U., and Brown, J. K. M. 2002. Isogamous, hermaphroditic inheritance of mitochondrion-encoded resistance to strobilurin fungicides in Blumeria graminis f. sp. tritici. Fungal Genet. Biol. 36:98-106.

33. Rossi, V., Caffi, T., and Legler, S. E. 2010. Dynamics of ascospore maturation and discharge in Erysiphe necator, the causal agent of grape powdery mildew. Phytopathology 100:1321-1329.

34. Salmon, E. S. 1900. A monograph of the Erysiphaceae. Mem. Torrey Bot. Cl. 9:1-292.

35. Salmon, E. S. 1903. Infection-powers of ascospores in Erysiphaceae. J. Bot. 41:159-165.

36. Skamnioti, P., Pedersen, C., Al-Chaarani, G. R., Holefors, A., Thordal-Christensen, H., Brown, J. K., and Ridout, C. J. 2008. Genetics of avirulence genes in Blumeria graminis f. sp. hordei and physical mapping of AVRa22 and AVRa12. Fungal Genet. Biol. 45:243-252.

37. Spanu, P. D., Abbott, J. C., Amselem, J., Burgis, T. A., Soanes, D. M., Stüber, K., van Themaat, E. V. L., Brown, J. K. M., Butcher, S. A., Gurr, S. J., Lebrun, M. H., Ridout, C. J., Schulze-Lefert, P., Talbot, N. J., Ahmadinejad, N., Ametz, C., Barton, G. R., Benjdia, M., Bidzinski, P., Bindschedler, L. V., Both, M., Brewer, M. T., Cadle-Davidson, L., Cadle-Davidson, M. M., Collemare, J., Cramer, R., Frenkel, O., Godfrey, D., Harriman, J., Hoede, C., King, B. C., Klages, S., Kleemann, J., Knoll, D., Koti, P. S., Kreplak, J., López-Ruiz, F. J., Lu, X., Maekawa, T., Mahanil, S., Micali, C., Milgroom, M. G., Montana, G., Noir, S., O'Connell, R. J., Oberhaensli, S., Parlange, F., Pedersen, C., Quesneville, H., Reinhardt, R., Rott, M., Sacristán, S., Schmidt, S. M., Schön, M., Skamnioti, P., Sommer, H., Stephens, A., Takahara, H., Thordal-Christensen, H., Vigouroux, M., Weßling, R., Wicker, T., and Panstruga, R. 2010. Genome expansion and gene loss in powdery mildew fungi reveal tradeoffs in extreme parasitism. Science:330:1543-1546.

38. Tanda, S. 1994. Ascospore formation and morphology in two species of the genus Erysiphe remaining immature on the living host plant. Mycoscience 35:141-145.

39. Troch, V., Audenaert, K., Wyand, R. A., Haesaert, G., Höfte, M., and Brown, J. K. M. 2014. Formae speciales of cereal powdery mildew: Close or distant relatives? Mol. Plant Pathol. 15:304-314.

40. Turner, D. M. 1956. Studies on cereal mildew in Britain. Trans. Br. Mycol. Soc. 39:495-506.

41. Wicker, W., Oberhaensli, S., Parlange, F., Buchmann, J. P., Shatalina, M., Roffler, S., Ben-David, R., Doležel, J., Šimková, H., Schulze-Lefert, P., Spanu, P. D., Bruggmann, R., Amselem, J., Quesneville, H., van Themaat, E. V. L., Paape, T., Shimizu, K. K., and Keller, B. 2013. The wheat powdery mildew genome shows the unique evolution of an obligate biotroph. Nat. Genet. 45:1092-1096.

42. Wolff, R. 1874. Keimung der Ascosporen von Erysiphe graminis Lév.Zugehörigkeit des Peridermium pini Lév. zu Coleosporium compositarum Lév. form. Senecionis. Bot. Z. 32:183-184.

43. Wyand, R. A., and Brown, J. K. M. 2005. Sequence variation in the CYP51 gene of Blumeria graminis associated with resistance to sterol demethylase inhibiting fungicides. Fungal Genet. Biol. 42:726-735.

44. Zhang, Z., Henderson, C., Perfect, E., Carver, T. L. W., Thomas, B. J., Skamnioti, P., and Gurr, S. J. 2005. Of genes and genomes, needles and haystacks: Blumeria graminis and functionality. Mol. Plant Pathol. 6: 561-575.

45. Zheng, Y., Luo, Y., Zhou, Y., Zeng, X., Duan, X., Cao, X., Song, Y., and Wang, B. 2013. Real-time PCR quantification of latent infection of wheat powdery mildew in the field. Eur. J. Plant Pathol. 136:565-575. 